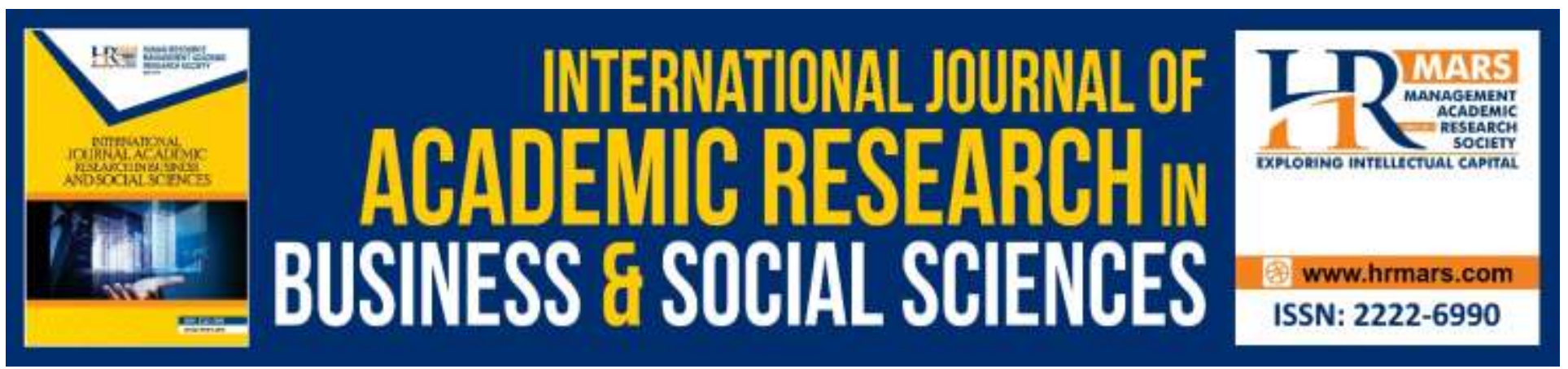

\title{
Application of Islamic Values in the Training Programs in Human Management at Institut Latihan Islam Malaysia (ILIM)
}

Abang Mohd Razif Abang Muis, Syamsul Azizul Marinsah, Abdul Hair Beddu Asis

To Link this Article: http://dx.doi.org/10.6007/IJARBSS/v10-i5/7193

DOI:10.6007/IJARBSS/v10-i5/7193

Received: 02 March 2020, Revised: 10 April 2020, Accepted: 29 March 2020

Published Online: 10 May 2020

In-Text Citation: (Muis et al., 2020)

To Cite this Article: Muis, A. M. R. A., Marinsah, S. A., \& Asis, A. H. B. (2020). Application of Islamic Values in the Training Programs in Human Management at Institut Latihan Islam Malaysia (ILIM). International Journal of Academic Research in Business and Social Sciences, 10(5), 273-280.

Copyright: @ 2020 The Author(s)

Published by Human Resource Management Academic Research Society (www.hrmars.com)

This article is published under the Creative Commons Attribution (CC BY 4.0) license. Anyone may reproduce, distribute, translate and create derivative works of this article (for both commercial and non-commercial purposes), subject to full attribution to the original publication and authors. The full terms of this license may be seen

at: http://creativecommons.org/licences/by/4.0/legalcode

Vol. 10, No. 5, 2020, Pg. 273 - 280

http://hrmars.com/index.php/pages/detail/IJARBSS

JOURNAL HOMEPAGE

Full Terms \& Conditions of access and use can be found at http://hrmars.com/index.php/pages/detail/publication-ethics 


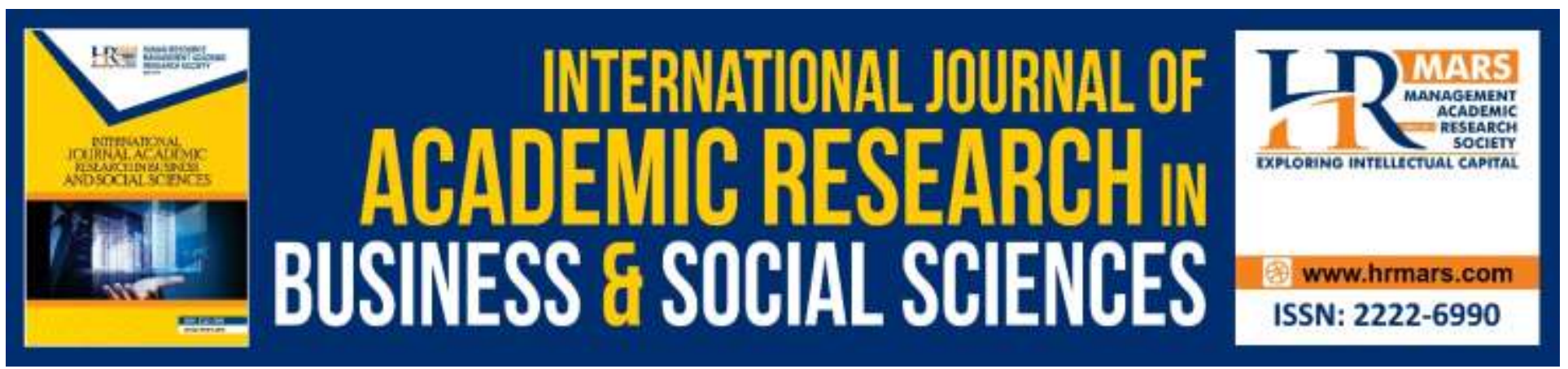

\title{
Application of Islamic Values in the Training Programs in Human Management at Institut Latihan Islam Malaysia (ILIM)
}

\author{
Abang Mohd Razif Abang Muis, Syamsul Azizul Marinsah, Abdul \\ Hair Beddu Asis
}

Centre for the Promotion of Knowledge and Language Learning, Universiti Malaysia Sabah

Email: amrazif@ums.edu.my, syamsulazizul@ums.edu.my,khairasis@ums.edu.my

\begin{abstract}
White collar crime issues involving Muslim workers are now a worrying phenomenon. Muslim workers like to lose the principles of Islamic values that should be a key part of their lives including in carrying out their duties and responsibilities within the institution. In addressing this, the aspects of the application and understanding of Islamic values among Muslim workers should be taken into consideration. Among the ways and mediums that can be used to do this is to implement training programs in human management that emphasize and apply Islamic values among the participants. As an Islamic-based training institute, the Institut Latihan Islam Malaysia (ILIM), should emphasize aspects of Islamic values in its training program. Therefore, this paper has two objectives. First, to identify the application of Islamic values in training programs in human management. Second, analyse the application of Islamic values in training programs in human management at ILIM. This paper uses document analysis methods and qualitative content analysis approached. The findings of the paper indicate that there are at least five Islamic values that need to be applied in training programs in human management namely values of courtesy, justice, trust, simplicity and selfreflection. In addition, it is also known that ILIM also incorporates these values into its training program either directly or indirectly. In conclusion, the application of all these Islamic values in training programs in human management especially at ILIM is very important in addressing issues of crime involving Muslim workers.
\end{abstract}

Keywords: Islamic Values, Training Programs, Human Management.

\section{Introduction}

Value is defined as the confidence that motivates an individual or institution to act in a way that is based on the values of society. An act or foundation of human thought that is in line with the Islamic value system is accepted as an Islamic act. In view of the system of pure values within the scope of Islamic law, it is based on monotheism that is the cornerstone of the value system philosophy (Abd. Aziz, 2011:42; INTAN, 1991). The application of the elements of Islamic values has been widely 
discussed by scholars. Aspects of values in Islam are more comprehensive and perfect than conventional values. This is based on the notion that everything that a human being does is considered to be worship including obedience and responsibility to Allah SWT, the head, the family, the institution and the nation. The perfection of values in Islam lies at its core. Its fundamentals are faith, sharia and morals. The sources are the Qur'an and the hadith. It also means that values in Islam have the strongest spiritual strength (Daud, 1994:146). These values can only be fully realized if they are linked to faith and piety to Allah SWT. If they cannot be linked and integrated, then those values will not work properly. (Sulaiman, 1997:19). Therefore, this paper has two objectives:

- To identify the application of Islamic values in training programs in human management.

- To analyse the application of Islamic values in training programs in human management at ILIM.

\section{Application of Islamic Values in The Training Programs in Human Management}

Although the application of values is not generally reflected in the principles of Islamic-based development, it remains one of the most important aspects in the context of training programs in Islamic-based human management. Through the scope of the research that has been carried out, there are several values that are fundamental to Islamic-based development. These include courtesy, justice value, trust value, moderation and self-reflection. These values are associated with the practice of virtues or praiseworthy traits that are contrary to those of the household or of the virtues. Islamic values are so important that they are emphasized in training programs in Islamic-based human management. This allows for the general welfare of the public and the workers in particular. For example, the value of trust in managing people's time, property and money. Workers who delay work lead to wasted time and money. Implementation of Islamic values is important to the quality of our own Muslims who will be an example and example to others. In the context of training programs in Islamic-based human resource management, aspects of skills, capabilities and knowledge in the work need to be completed, but it must start with the construction and application of Islamic values first so that the people or workers born are superior and of quality. The descriptions of each value are as follows:

\section{Courtesy}

The value of courtesy means that Allah SWT sees all human actions, whether explicit or implicit (Daud, 1994:148). Therefore, a worker needs to believe that every act of management is seen by Allah SWT. On the other hand, compassionate, kind and considerate in managing the institution. Allah SWT has promised heaven to His servants who possess these attributes. ${ }^{1}$ The value of courtesy found in this Qur'an is also described by the Prophet Muhammad SAW in several hadiths. ${ }^{2}$ Therefore, kindness is when the spirit and the mind realize that Allah SWT is watching. Feel that Allah SWT sees, hears, evaluates and feels Allah SWT governs and governs mankind. Courtesy can be divided into two main

\footnotetext{
${ }^{1}$ This is in line with the word of Allah SWT which means: (This will be) their cry therein: "Glory to Thee, O Allah." And "Peace" will be their greeting therein! and the close of their cry will be: "Praise be to Allah, the Cherisher and Sustainer of the worlds!" (Yunus, 10:26).

${ }^{2}$ For example, the Prophet's SAW words in the hadith of Jibra'il when he was asked by the Jibra'il a.s. which means: "Then he (Jibra'il) asked again: O Messenger of Allah, what is courtesy? He said: "(It is) that you worship Allah SWT as if you saw Him. If you cannot see Him, surely, He (Allah SWT) will surely see you" (Riwayat al-Bukhariy, No. Hadith:48).
} 
areas of courtesy and courtesy. Courtesy in worship is a person who worships Allah SWT with great sincerity and sincerity as if he were dealing with Allah SWT. Kindness in your heart also has two meanings. First, courtesy is the gift of goodwill, it is the care of specific interests that are or should be owned by certain parties and improve the quality of work. This meaning can be seen through family and Islamic community activities (Omar, 2001:62; Ahmad, 2008:209; Shapik, 2014). For the second definition, courtesy is seen in the context of employment and institutional management. Courtesy means improving the quality of work, comprehensive knowledge and good skills (Shapik, 2014). Abdul Wahab (2008:24) in particular, explained the meaning of courtesy by giving more than the tasks required, working better than the assigned tasks, over time and delivering the best service without expecting anything in return. In the end, the manager or employee will be the employee who can fulfill his or her responsibilities as an employee and at the same time, reward the results of worship performed by Allah SWT. According to the statement, the practice of the concept of courtesy will produce workers who have the qualities that Allah SWT likes, earnest, trustworthy, timely and so on, because they know they work for Allah SWT. They feel that everything they do is worship, so all their actions will be observed by Allah SWT even though they cannot see Allah SWT. ${ }^{3}$

\section{Justice}

In terms of language, justice means putting things in the right place. Justice also refers to equality and the giving of rights to the right (AlHabshi, 1998:214). In terms of terms, justice means putting something in place based on the rules of faith, shariah and morality based on the Qur'an and the hadith (Daud, 1994:148). ${ }^{4}$ Justice does not mean equality. For example, as a result of gender differences, there are generally jobs that are good for one side and not good for the other. Therefore, justice is always associated with equality. Justice in Islam is measured through the Qur'an and the hadith and is not interpreted according to human desires. Justice value has a positive effect. It can prevent abuse and will promote trust and fairness. It is one of the values of the nature of the people who love to be treated fairly and reduce dissatisfaction among institutional members. In the context of management, justice covers all aspects and areas of regulation, law, values, ethics, training and so on. In the context of training programs in human management, each training program should be provided to eligible employees. ${ }^{5}$

\section{Trust}

Trust is something that must be safeguarded and given to those who deserve it. When a person fails to perform the trust, he or she is betrayed because the goal of the trust is to achieve justice. Absolute justice is only the property of Allah SWT. However, humans are still required to work for trust. Trust

\footnotetext{
${ }^{3}$ This means, courtesy not only in the aspect of worship but also in other aspects of life as Allah SWT says: Men who celebrate the praises of Allah, standing, sitting, and lying down on their sides, and contemplate the (wonders of) creation in the heavens and the earth, (With the thought): "Our Lord! not for naught Hast Thou created (all) this! Glory to Thee! Give us salvation from the penalty of the Fire. (Ali 'Imran, 3:191).

${ }^{4}$ Allah SWT has emphasized the obligation to always uphold justice in all matters and circumstances through His word which means: O ye who believe! stand out firmly for Allah, as witnesses to fair dealing, and let not the hatred of others to you make you swerve to wrong and depart from justice. Be just: that is next to piety: and fear Allah. For Allah is wellacquainted with all that ye do (al-Ma'idah, 5:8).

${ }^{5}$ In connection with this, Allah Almighty has said: Allah doth command you to render back your Trusts to those to whom they are due; And when ye judge between man and man, that ye judge with justice: Verily how excellent is the teaching which He giveth you! For Allah is He Who heareth and seeth all things (al-Nisa', 4:58).
} 
can bring peace and prosperity to society (Din, 2015:72; Ahmad, 2011:82). Trust is also associated with cleanliness and efficiency. It means being morally, morally and ethically clean in the way of doing one's job, not abusing authority, not being arrogant and not involved in crime and corruption. Being physically clean is like having a healthy, active and organized body. Efficiency is also related to excellent job performance and quality aspects. Trust is a value in the management of institutions that are very important in Islam. Islam emphasizes that top-down planning must be trustworthy, honest and fair in the management of an institution including Islamic institutions. In addition, being bold in replying wisely includes being trustworthy (Daud, 1994:149). Work with trust results in worship. Management in Islam is a process of perfecting trust. Trust is a very important key to a successful career. The highest trust in work is trust in Allah SWT. This means that a person is doing his work sincerely, as well and as reasonably as possible with the belief that Allah SWT knows every single thing that a person does, and that work brings benefits and benefits to others and institutions. This work is not only a responsibility but at the same time, Allah SWT rewards the reward and bestows His grace and blessing. Trust in Allah SWT will also have a positive impact on institutions and people (Baba, 2012). Implementing the value of trust in training programs in human management is crucial. It is based on issues of moral collapse and human nature such as misconduct, corruption and others that prove that humans are increasingly greedy for material wealth and success despite having to sacrifice their faith and values. ${ }^{6}$ Therefore, a worker especially in an Islamic institution is strictly prohibited from practicing the policies of nepotism, cronyism, corruption and exploiting his position and position for his personal benefit. Finally, the Prophet Muhammad SAW warned the Muslims of the loss of trust in the Muslim community in the future. It is also a small sign of the end of days. ${ }^{7}$

\section{Simplicity}

Islam strongly encourages the value of moderation in all things. Islam itself is a simple religion and its people are exemplary in its simplicity. Moderation is encouraged by Islam in many areas including matters of worship, daily life, work and so on. ${ }^{8}$ According to the word of Allah SWT, simplicity is an attitude that rejects the extremes of any exaggeration in the regulation, expenditure and so on. Simplicity in Islamic teaching is a balance in meeting the demands of the world and the afterlife (AlBakri, 2011:27). In the context of human resource management in an institution, a simple manner of speaking, giving directions, interacting, dressing properly and so on is very important for increasing the efficiency and productivity of an institution. Therefore, the application of the value of moderation in training programs in human management should be given priority and attention.

\footnotetext{
${ }^{6}$ The Prophet Muhammad SAW emphasized this in a hadith narrated by Anas bin Malik r.a. which means: "It is incomplete in the faith of anyone who does not fulfill the trust and the imperfect religion of one who does not keep his promise." (Riwayat Ahmad, No. Hadith: 12722).

${ }^{7}$ The Prophet SAW emphasized this in a hadith narrated by Abu Hurairah r.a. which means: "If the trust is destroyed, just wait for the destruction to take place." A friend asked, "What does trust mean?" The Messenger of Allah (may peace be upon him) replied, "If the matter is not given to its members, then wait for it to be destroyed" (Riwayat al-Bukhariy, No. Hadith: 6015).

${ }^{8}$ This is in line with the word of Allah SWT which means: "Say: Call upon Allah or call upon Rahman: by whatever name ye call upon Him, (it is well): for to Him belong the Most Beautiful Names. Neither speak thy Prayer aloud, nor speak it in a low tone, but seek a middle course between." (al-Isra', 17:110), O Children of Adam! wear your beautiful apparel at every time and place of prayer: eat and drink: But waste not by excess, for Allah loveth not the wasters. (al-A'raf, 7:31), Call on your Lord with humility and in private: for Allah loveth not those who trespass beyond bounds (al-A'raf, 7:55).
} 


\section{Self-Reflection}

In the context of Islamic-based development, one of the ways to improve the quality and quality of work that is the responsibility of an employee for success is to evaluate one's own weaknesses, shortcomings, mistakes and mistakes. Self-awareness needs to be done by listing all the weaknesses that one has done and trying to overcome it and trying to prevent it from happening again (Kamri, 2006:95). Therefore, any training program in human management should inculcate self-reflection so that each participant is able to assess their own weaknesses and thus improve themselves to become better person or employees in the future. ${ }^{9}$ Allah SWT emphasizes the command to reflect on this self by beginning and ending with the word piety. This clearly demonstrates that the reason for doing so should be based on the inanity and the fear of Allah (Alwi, 2008:209)..$^{10}$

In the context of training programs in human management, the value of self-reflection is of no importance. Self-awareness is a form of spiritual practice for the healing of the soul and also has a positive impact on the human body. Through the practice of evaluating, examining and improving this self, everything that is done will be rethought. These self-reflective values need to be present in every training program in human management implemented so that each employee is able to evaluate, evaluate and improve themselves upon completing a training program. Existing strengths and opportunities are taken into account and every weakness is overcome, corrected and action taken immediately (Kamri, 2006:95). For that purpose, self-reflection needs to be done consistently either individually or in groups. This continuous and consistent process of self-reflection is an important foundation that is developed so that in the end human hearts and minds are more inclined to be obedient and obedient to the values of Islam that they need to have (Kamri, 2006:95; Baba, 2012).

\section{Analysis of The Application of Islamic Values in The Training Program in Human Management At Institut Latihan Islam Malaysia (Ilim)}

As discussed earlier, in general, the application of Islamic values is not reflected in the principles of Islamic-based development. However, the application of these Islamic values remains an important aspect especially in the context of Islamic-based training programs in human management. There are some values that are embodied in Islamic values that must be found in the basics of Islamic-based training programs in human management. These include courtesy, justice, trust, simplicity and selfreflection. These values are associated with commendable practices that go against the bad habits that are created through Islamic-based training programs in human management. The ILIM training program is also not exempt from emphasizing the value of courtesy. The training program offered by ILIM that specifically emphasizes the value of courtesy is the Islamic Management Course. This training program aims to expose the Islamic management system in the public service and enhance the charitable aspects of raising civil servants' competencies. The content of this training program is about the application of courtesy and charity (amal jama'i) to the work and management especially in the public service. Among them are Basic Law Drafting Courses, Understanding and

\footnotetext{
${ }^{9}$ This is in line with the word of Allah SWT which means: O ye who believe! Fear Allah and let every soul look to what (provision) He has sent forth for the morrow. Yea, fear Allah. for Allah is well-acquainted with (all) that ye do. (al-Hasyr, 59:18).

${ }^{10}$ The Prophet SAW said: "Every person must make a mistake and the best person who makes the mistake is the one who always repents" (Riwayat Tirmidzi, No. Hadith: 2423).
} 
Implementation of Islamic Family Law, Appeal Management and Syariah Criminal Case Review Courses, Syariah Law Introduction of Syariah Law in Malaysia Courses, Family Law Seminars, Syariah Prosecution Skills Courses, Comparation of Islamic and Civil Law Systems in Malaysia Courses, Legal Discussions, Understanding Islamic Law Administration in the Islamic Administration Office Courses and Islamic Law Courses (ILIM, 2016).

The value of trust is one of the key Islamic values that ILIM has implemented in its human resource management training program. There are several training programs offered by ILIM that emphasize the value of trust in work and life. Among them are High Level Leadership Courses, Testimonial Skills Courses, Islamic Thought Courses, Islamic Property Management Courses, Mosque Management and Finance Courses, Waqf Management Courses and Zakat Management Courses. In all of these ILIM training programs, the value of trust in the working context is emphasized among the participants to enhance public confidence in the organization. The value of simplicity can also be examined in terms of the form of the ILIM training program. There are several training programs offered by ILIM that emphasize the value of simplicity in work and life. Among them are Shariah-based Finance Courses, Preaching Leadership and Management Courses and Preaching Methodology Courses. Self-reflective values are also foundational to the application of Islamic values in training programs in human management. Although not explicitly stated in the ILIM training program, self-reflective values are still incorporated by ILIM in the training program it offers. There are several training programs offered by ILIM that emphasize the value of self-reflection. These include Retirement Preparatory Courses, Strategic and Personal Development Courses and Preaching and Human Development Courses (ILIM, 2016).

\section{Conclusion}

In conclusion, the application of Islamic values in humanitarian management training programs at ILIM will facilitate efforts to develop various sectors and types of Islamic institutions such as religion, education, banking, finance, socioeconomics, administration, medical, community, law, military and so on. Such belief in Islamic values will also have a positive effect on society over the long term. The application of these Islamic values will also enable the workers to know their Creator, Allah SWT and to develop strong faith and to build a strong identity. In term of contextual contributions, this paper can be a basic and the right direction to anyone who want to look for further studies on the Islamic institution's managements. This is also a good start in term of development more Islamic-based values to the multi-disciplinary subjects especially on management field.

\section{Corresponding Author}

Abang Mohd Razif Abang Muis can be contacted at amrazif@ums.edu.my

\section{References}

Abd. Aziz, S. W. M. (2011). Pemahaman dan penghayatan nilai menjana kepada prestasi: Pengalaman Jabatan Kemajuan Islam Malaysia (JAKIM). In Pemahaman dan penghayatan nilai menjana kepada prestasi. Kuala Lumpur: Institut Kefahaman Islam Malaysia (IKIM).

Abdul Wahab, M. N. (2008). Kecemerlangan pengurusan organisasi dalam Islam. Kuantan: Penerbit Universiti Malaysia Pahang (UMP).

Ahmad, H. (2008). Institusi Islam. Kuantan: Penerbit Universiti Malaysia Pahang (UMP). 
INTERNATIONAL JOURNAL OF ACADEMIC RESEARCH IN BUSINESS AND SOCIAL SCIENCES

Vol. 10, No. 5, May, 2020, E-ISSN: 2222-6990 @ 2020 HRMARS

Ahmad, R. (2011). Konsep personaliti unggul dan ciri-ciri pekerja cemerlang. In Abd Jalil Borham, Ahmad Fazrullah Mohd Zainal Abidin, Hassan Ahmad, \& Munira Abdul Razak (Eds.), Mengangkasa modal insan: Isu dan cabaran. Kuantan: Penerbit Universiti Malaysia Pahang (UMP).

Al-Bakri, Z. M. (2011). Wasatiyyah: Konsep dan pelaksanaannya. Kuala Lumpur: Yayasan Dakwah Islamiah Malaysia (YADIM).

AlHabshi, S. O. (1998). Pembangunan Manusia dalam Pengurusan. In Syed Othman Alhabshi \& Hamiza Ibrahim (Eds.), Pengurusan dan Pentadbiran: Mencapai Kecemerlangan Melalui Penghayatan Nilai (pp. 193-216). Kuala Lumpur: Institut Kefahaman Islam Malaysia (IKIM).

Alwi, E. A. Z. (2008). Apa itu Islam. Batu Caves: PTS Publications \& Distributions.

Baba, S. (2012). Pengurusan Islami: Aplikasi ihsan dan insan. Kuala Lumpur: Techknowlogic Trading Sdn Bhd.

Che Omar, A. (2001). Pengurusan di Malaysia dari perspektif Islam. Kuala Lumpur: Dewan Bahasa dan Pustaka.

Daud, M. (1994). Pengurusan Islam. Kuala Lumpur: Utusan Publications \& Distributors.

Din, H. (2015). Manusia dan Islam: Jilid 2. Kuala Lumpur: Dewan Bahasa dan Pustaka.

ILIM. (2016). Program Latihan ILIM dan ILTIM 2016. Bangi: Institut Latihan Islam Malaysia (ILIM).

INTAN. (1991). Nilai dan etika dalam perkhidmatan awam. Kuala Lumpur: Institut Tadbiran Awam Negara (INTAN).

Kamri, N. A. (2006). Pengurusan sumber manusia menurut perspektif Islam. In Ab Mumin Ab Ghani \& Fadillah Mansor (Eds.), Dimensi Pengurusan Islam: mengurus kerja dan mengurus modal insan (pp. 83-101). Kuala Lumpur: Penerbit Universiti Malaya.

Shapik, M. Z. (2014). Penghayatan konsep ihsan ke arah melahirkan tenaga kerja berprestasi tinggi. Konvensyen Latihan Islam Peringkat Kebangsaan Kali Ke-3. Bangi: Institut Latihan Islam Malaysia (ILIM).

Sulaiman, S. T. (1997). Pengurusan Islam dan pembangunan manusia. Batu Caves: Thinker's Library Sdn. Bhd. 